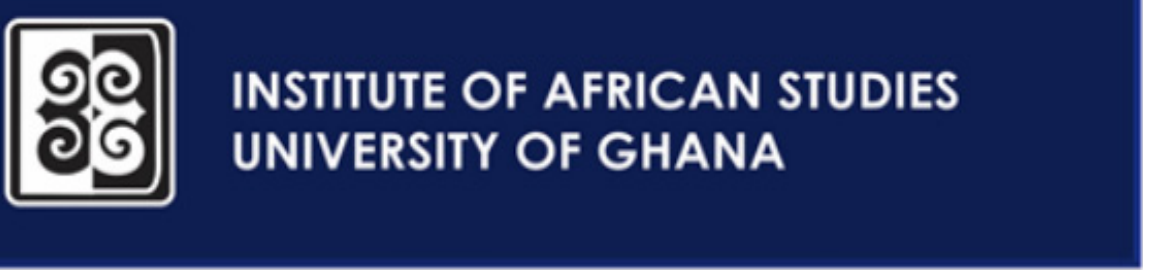

Contemporary Journal of African Studies 2019; 6 (1): 138-157

https://dx.doi.org/10.4314/contjas.v6i1.8

ISSN 2343-6530

(C) 2019 The Author(s)

Open Access article distributed under the terms of the

Creative Commons License [CC BY-NC-ND 4.0]

http://creativecommons.org/licenses/by-nc-nd/4.0

\title{
Towards a Pan-African political culture: Critical pedagogy, reparative justice and the end of global white supremacy
}

\section{Ikaweba Bunting}

Director, Mwalimu Nyerere Foundation's African Unity Department

Author'semail: i.bunting@nyererefoundation.org

\begin{abstract}
This paper is an extension of previous work on African peoples' experiential knowledge, cognitive interests, contested political and cultural power. African centered critical pedagogy, reparatory justice and Pan African political culture are presented as integral to realizing emancipation from the destruction of imperialist domination. The paper posits that to realize AU Agenda 2063 and the global Pan African aspirations, a Pan African political culture must be inculcated in all institutions of the African world. Challenges related to the Pan African Movement and realization of the AU Agenda 2063 are noted. Rather than a consensus of meaning, ideological clarity and strategic purpose, a dissonant cacophony of ideas and agendas proliferate. The paper notes a disconnect between African governments' state centric approach to Pan Africanism and the endogenous people centric Pan Africanism, and despite recognition of the need for Pan Africanist institutions and policies there is an absence of cohesive and persistent effort, clarity of purpose and sustainable institutional support. It concludes that there is a general consensus that continental political unity, global Pan African solidarity, participatory democracy and non-capitalist people centered economy are fundamental to the Pan African purpose, and global Pan African organization is necessary for African peoples to regain power of political self-determination, overcome impoverishment, racial based oppression and the structural violence of global white supremacy.
\end{abstract}

Keywords: critical pedagogy, Pan African, African-centered, political culture, ideology, Euro-American, epistemology, subalterns, imperialism, Global-NATO, justice, reparations 


\title{
Towards a Pan African Political Culture: Critical Pedagogy, Reparative Justice and the End of Global White Supremacy
}

\author{
Ikaweba Bunting
}

\begin{abstract}
This paper is an extension of previous work on African peoples' experiential knowledge, cognitive interests, contested political and cultural power. African centered critical pedagogy, reparatory justice and Pan African political culture are presented as integral to realizing emancipation from the destruction of imperialist domination. The paper posits that to realize AU Agenda 2063 and the global Pan African aspirations, a Pan African political culture must be inculcated in all institutions of the African world. Challenges related to the Pan African Movement and realization of the AU Agenda 2063 are noted. Rather than a consensus of meaning, ideological clarity and strategic purpose, a dissonant cacophony of ideas and agendas proliferate. The paper notes a disconnect between African governments' state centric approach to Pan Africanism and the endogenous people centric Pan Africanism, and despite recognition of the need for Pan Africanist institutions and policies there is an absence of cohesive and persistent effort, clarity of purpose and sustainable institutional support. It concludes that there is a general consensus that continental political unity, global Pan African solidarity, participatory democracy and non-capitalist people centered economy are fundamental to the Pan African purpose, and global Pan African organization is necessary for African peoples to regain power of political self-determination, overcome impoverishment, racial based oppression and the structural violence of global white supremacy.
\end{abstract}

Keywords: Critical Pedagogy; Pan African; African-Centered; Political Culture; Ideology; Euro-American; Epistemology; Subalterns; Imperialism; Global-NATO; Justice, Reparations.

\section{Résumé}

Cet article est une extension des travaux précédents sur les connaissances expérientielles, les intérêts cognitifs et le pouvoir politique et culturel contesté des peuples africains. La pédagogie critique centrée sur l'Afrique, la justice réparatrice et la culture politique panafricaine sont présentées comme faisant partie intégrante du processus de la réalisation de l'émancipation face à la destruction de la domination impérialiste. L'article avance que pour réaliser l'Agenda 2063 de l'UA et les aspirations panafricaines mondiales, une culture politique panafricaine doit être inculquée à toutes les institutions du monde africain. Les défis liés au Mouvement panafricain et à la réalisation de l'Agenda 2063 de l'UA sont notés. Plutôt qu'un consensus de sens, de clarté idéologique et d'objectif stratégique,

https://dx.doi.org/10.4314/contjas.v6i1.8

Professor Ikaweba Bunting (Email address: i.bunting@nyererefoundation.org) is the current Director of the Mwalimu Nyerere Foundation's African Unity department. He is also the Acting Secretary General of the Global Pan African Movement and International Organizing Committee for Pan African Congress. Professor Bunting has consulted for the United Nations and various international non-governmental organisations. A Professor of Sociology, Political Science and Africana Studies, Bunting has taught and lectured at The International Training Centre for Development Cooperation in Tanzania, The Centre for Development Studies at the University of Wales (UK), Loyola Marymount University of Los Angeles, California State University of Long Beach and Compton Community College. The author of several articles on Pan Africanism, Critical Pedagogy, Socio-economic Development, Politics, Democracy and Conflict in Africa, he conducted the last interview of President Julius Nyerere, just prior to Nyerere's death in 1999. Professor Bunting uses his skills and expertise to contribute to institutional development, and enhance linkages between policy implementation bodies, NGOs, academia and grassroot communities with the objective of improving life chances for impoverished and at risk communities of African peoples globally. Raised in Compton CA, Ikaweba immigrated to Tanzania in 1974 and became a Tanzanian citizen. He earned his PhD in International Development Studies from the University of Wales in 1998. 
une cacophonie dissonante d'idées et d'agendas prolifère. L'article note un décalage entre l'approche centrée sur l'Etat adoptée par les gouvernements africains à l'égard du panafricanisme et le panafricanisme centré sur les peuples endogènes et, que malgré la reconnaissance de la nécessité d'avoir d'institutions et de politiques panafricanistes, il manque d'efforts cohérents et persistants, de clarté des objectifs et de soutien institutionnel durable. L'article conclut qu'en général l'unité politique continentale, la solidarité panafricaine globale, la démocratie participative et une économie centrée sur le peuple non capitaliste sont certainement fondamentaux pour la réalisation de l'objectif panafricain et qu'une organisation panafricaine mondiale est nécessaire pour que les peuples africains puissent regagner le pouvoir d'auto-détermination politique, et surmonter l'appauvrissement, l'oppression raciale et la violence structurelle de la suprématie blanche.

Mots-clés : Pédagogie critique ; pan africain ; Centré(e) sur l'africain ; culture politique ; idéologie ; euro-américain ; épistémologie ; subalternes ; impérialisme ; OTAN globale ; justice ; réparations

\section{Introduction}

The African pedagogue by necessity must be a 'guerilla intellectual'. Considering the current world order and state of affairs of the Global African family, education geared towards fulfilling the needs of African peoples, must be an emancipatory experience. The African 'guerilla intellectual' is an education freedom fighter. The 'guerilla intellectual' uses and adapts the instruments' of the conquerors and oppressors, their methodologies, philosophies, ideas and episteme to deconstruct the invented structures, false knowledge and cultural myths that perpetuate the social domination, economic exploitation and cultural dehumanization of African peoples (Hill, 1990).

Just as the freedom fighter in the African anticolonial wars of liberation engaged in a military struggle against superior and repressive forces had to capture and use the weapons of the enemies of freedom, the African guerilla intellectual must capture the pedagogical, ideological and cultural weapons used by the enemies of African self-determination, adapt them and turn them against that enemy in an act of epistemological and cultural emancipation.

Critical pedagogy can facilitate an intellectual and epistemological liberated zone wherein authentic cognitive interests of African peoples has the space to generate a new social political discourse, a new knowledge, a new way for conscious African agency to inform the 'motion-matter-energy' relationship of social interaction for the reparation and benefit of societies impoverished and dehumanized by the Euro-American imperialist confluence.

Critical pedagogy facilitates the uncovering of the dynamic relationships of the motion-matter-energy dialectic in the world of human interaction and the nature of the manipulations of those relationships (Giroux, 2010; Freire, 1993). The social, political and economic outcomes of such manipulations occur within a specific cultural framework and social purpose that inform the agency and intent of those manipulations. Is that agency emancipatory or repressive? Is it life affirming or life negating? Does it 
promote the collective wellbeing or is it selfish individualism at the expense of community? With these questions in mind, we understand that we are in a Battlefield of Knowledge (Long and Long; 1992).

I speak of a battlefield of knowledge particularly as it relates to the construction of knowledge regarding African peoples objectified and defined 'subaltern' within the Euro-American imperialist confluence circa 1400 to the present. The modernist's philosophical framing categorized the world into a racial and cultural hierarchical binary of the Occidental 'Norm' vs. the 'Other'. This normative power articulated becomes White Superior/Black Inferior; European Civilized/African Uncivilized; Euro-America Developed/ Africa Underdeveloped.

African centered critical pedagogy is predicated upon reclaiming historical authenticity, liberating the intellectual capacity, agency and cultural power to challenge and deconstruct this Euro-American imperialist confluence and its accompanying myths of superiority/inferiority and legitimization of distorted knowledge and White supremacy (American Exceptionalism) mythological narrative of human history and culture.

The construction, codification and distribution of knowledge occur within a cultural framework with specific cultural tools, informed by a specific worldview. The learning of cultural norms, values, and social interactive etiquette is a socialization process (Hilliard III, 1998). The learning process and the informational content of what shall be knowledge and uses, therefore, have culturally determinant political, social and economic elements. Some community based culturally affirmative socialization educational practices of African descendant peoples contain residues of indigenous African pedagogical systems. However, the enslavement/colonialisation dehumanization purpose and its acts of cultural genocide aimed at destroying, devaluing and undermining African cultural reproduction have rendered those pedagogical systems uncivilized, alienated and consequently in a state of atrophy and cultural depreciation (Ibid).

An African centered critical pedagogy, a Pan African political culture and a program of Reparatory Justice provide a model for the ontological selfactualization, cultural emancipation and political empowerment for African peoples and states. This construct can provide the basis to undo the structural, cultural and epistemological manifestations of the dehumanizing intent upon which the Euro-American imperial confluence continues to substantiate its dominion and exploitation of Africa and its peoples. Considering the devastation and societal dislocation that the invasions, conquests, enslavement and colonialisation of Africa created, it cannot be denied, nor should it be denied that African peoples have been, at best, severely damaged and disabled by way of the enslavement/colonization socialization process to which they 
have been subjected. The institutions of science, education, religion and law of the Euro-American world order created the subaltern African. It is through a comprehensive program of reparatory justice that Africans will be empowered to move from disabled to abled, be made whole again to emancipate themselves from the institutional oppression, exploitation, and alienation of the existing world order.

\section{Reparatory Justice}

Reparatory justice is an elaboration of the historical calls and demands for reparations for Africa and peoples of African descent harmed and dehumanized as a direct consequence of the Trans-Atlantic Slave Trade and colonialisation of the continent. Taken as a whole the conquering, enslavement and colonialisation of Africa by European and American states and state protected trading corporations traumatized the humanity, destroyed social-cultural structures and exploited the economic and human resources of Africa.

Reparatory justice therefore includes more than monetary compensation to the descendants of the human and institutional victims. It takes into account the entire 500 years epochal injustice and the contemporary manifestations of its continuum of social, psychological and cultural harm that require remedies. Reparatory justice provides the framework for the human and institutional descendants of the enslavement, colonialisation confluence for redress and healing. Because we are talking about communities of peoples and a continent's societies, cultural, human and natural resources needing to be made whole again, liberal justice informed by the ideology of individualism, with its focus on the rights of the individual person, is insufficient.

The global financial and economic system, the preeminent political ideology and governance system of the current world order of power and wealth distribution is predicated upon the disempowerment and continued exploitation of Africa and African peoples. AU Agenda 2063 is, in its essence, inherently antithetical to the world order status quo. It is also antithetical to the future of Africa as envisaged in the strategic policy and power projections of the U.S.-EU imperial confluence or 'Global NATO' (Campbell, 2013). Consequently, in order to realize the objectives of Pan African unity and the socio-economic goals of AU agenda 2063, the mechanisms and ideologies of the preeminent world power structure must be exposed, delegitimized and deconstructed. Action is urgently required to implement a policy to inculcate a Pan African political culture into the institutions of African societies, organizations, political parties and governments. 


\section{African Centered Critical Pedagogy}

To realize a Pan African political culture there is an urgent and pressing need for African centered curriculum articulated through a critical pedagogical methodology in our schools, colleges, training centers and universities. Such a pedagogical model is substantiated and informed by an emancipatory purpose intended to foster the philosophical disposition, the political will and socio-economic power to realize global Pan African objectives and the social political and economic transformation of Africa.

This African centered critical pedagogy coupled with a Pan African political culture and a program of reparatory justice is an indispensable instrument that will enable the deconstruction and elimination of the global racial and cultural hierarchy that locates the Euro-American imperial confluence and Europeans at the center of the human philosophical, cultural and scientific narrative. An African Centered Critical Pedagogy necessarily facilitates African students and societies acquiring the capabilities, tools and ideological framework to explore the world from the epistemological perspectives and cultural vantage point of the continuum of experiences of African peoples (Asante, Molefi, 1990; Kincheloe, 2008).

This model opposes, in stark contrast, the epistemological perspectives and global socio-historical narrative Euro-American world order that informs and underpins the educational philosophies, ideas of democracy and societal progress that dominate and inform African governance, policy formulation processes and goals. (Kincheloe, 2008). Throughout the African world, we copy the symbols, institutional structures and ethos of Europe and America. Take, for example, the persistent wearing of powdered blonde wigs among African and Caribbean jurists as a symbol of authority and status. Another example is the manner in which world history, and in particular African history, is chronicled in relation to European events, individuals and ideas. We teach our youth about Pre-colonial, Post-colonial Africa or Pre-Columbian history for the Americas, thus situating all peoples' and nations' historical narrative relative to developments and actions of Europe and Europeans. In other words, we narrate our historical experience and tell historical time around being 'discovered' by Columbus or Vasco da Gama or being colonized by Cecil Rhodes.

Critical Pedagogy allows us to question, critique and understand how this positions Africa as a perpetual disempowered subaltern. Essentially, we are arguing that an African centered critical pedagogy coupled with a program of reparatory justice are integral components to realizing and informing a Pan African political culture. Consequently, through the utilization of this model the peoples and societies of Africa will be able to carry out the destruction of racialized imperialist domination of Africa and African Peoples and thereby 
bring about the subjective and objective conditions for realizing the highest ideals of Pan Africanism and the AU agenda 2063.

Let us briefly examine the concepts and purpose of 'critical pedagogy'. The critical pedagogical paradigm is located in the reality of power. This reality includes the power to define, and determine what is knowable and who controls the production, codification, validation and distribution of knowledge. Subsequently power realignment and redistribution becomes a central component of the method and the end purpose of the educational experience (Giroux, 2010; Freire, 1993). The foundational aspect of this paradigm is emancipatory for oppressed, exploited and disempowered peoples. Critical pedagogy makes the distinction between education and schooling. Education is transformative, leading to skills acquisition and knowledge of self (collective and individual) within an historical context of socio-economic and cultural interactions. Education, as opposed to training or schooling, for oppressed and marginalized people needs to be totally different from that of the dominant society that is predicated upon maintenance of the socioeconomic and political order that advantages one segment of humanity over another such that one is impoverished and the other enriched and privileged (Shockley and Cleveland 2011).

Critical pedagogy is crucial to a formative culture that makes critical consciousness as social action possible. Real education empowers the oppressed and marginalized, the cultural and historically alienated, to emancipate their indigenous agency and shape or reshape the world. Critical pedagogy links learning to social change (Giroux, 2010). An African centered critical pedagogy assists students and teachers to become conscious of the forces that have ruled and shaped their lives and consciousness. Education within the framework of critical pedagogy is a political and value full cultural practice intended to enable learners to investigate their selves in relation to the social and economic conditions within which they interact. The critical paradigm allows for self-actualization through engagement and expansion of their participation in governance and socio-economic self-determination (Shockley and Cleveland 2011; Freire, 1993). It is, in short, education for self-reliance and self-determination.

Africancentered critical pedagogy provides the space andlegitimization of experiential knowledge of African peoples related to the workings of, and resistance to, imperialism, colonialism, enslavement, Jim Crow apartheid and white supremacy racism. Legitimizing this knowledge and including it in the curriculum is essential for a Pan African transformative emancipatory educational paradigm. Such a pedagogical paradigm empowers the least, the most oppressed and values their experiences as a central resource to the shaping of Africa's future. Experience hereby works in tandem with theory (Cabral, 1979; Lema et al. 2004). African peoples across the globe have 
been historically and continuously subjected to training and indoctrination encapsulated in training to learn the rudiments the social sciences, physical sciences, mathematics and especially literature and history. The education to which we have been subjected to, and that we continue to subject our children, is modelled and informed by the system and values of the conquerors and enslavers of Africa.

In this Euro-American centric paradigm, subservience to authority and the Euro-American narrative was paramount. This mal-education is grounded upon assumptions and attitudes of an imperialist, racialist capitalist society and belief system. The emphasis of individualism over collectivism is encouraged and propagated. It promotes ostentatious consumption and celebrates individual acquisition of wealth as the most significant determinant of merit and human worth (Nyerere, 1967; Ani, 1994). Corruption and undemocratic governance in Africa is a direct result and manifest function of this indoctrination and mal-education!

Said paradigm and pedagogical approach dominates the world of academics and policy and as such inculcates attitudes and practices of inequality and domination of the weak by the empowered and privileged. The imposed order devalues local knowledge, wisdom, custom and epistemological framework (Nyerere, 1967).

The post enslavement, colonial and neo-colonial education has been a continuous and deliberate formulation to undermine, disparage and replace long-established knowledge, wisdom and values of free Africans and independent African societies. To be learned and civilized one necessarily needs to be alienated from the indigenous, thus alienating the people from their knowledge base, their cultural values and their epistemological selfdetermination; this is key to the neo-colonial and imperialist project (Fanon, 1963; Nyerere, 1967; Cabral, 1979). The content, purpose, and methodological paradigm of our education are a function of the type of society we wish to build (Lema, et al. 2004). We cannot have an educational system predicated upon competition, historical distortion, racialist hierarchical framing and individualism if we want a cooperative egalitarian and unified Africa. The two are mutually exclusive!

\section{Pan African Political Culture and the End of Global White Supremacy}

As evidenced and recorded in personal and communal orature, historical narratives, academic research, novels, artistic performances and volumes of socio-economic studies, African peoples share elements of a common experience over the past six centuries. That experience has fostered ideas of common identity and social movements based upon that shared identity of experience. Pan Africanism as an idea and an objective has envisaged a unity 
of purpose toward forging a political, cultural and economic power informed by that shared experiential knowledge to liberate African peoples from the structures that imposed and maintain their subordinate status in global social economic order.

The most persistent and resilient of the ideas is Pan Africanism. Pan Africanism is born of the ideation of African peoples simultaneously in different parts of the globe at different times in the history of the six hundred years of Euro-American imperial confluence. The term Pan Africanism did not generate the idea of Pan Africanism. Rather experiential knowledge of the cause and effects relationship between French, British, Spanish, Portuguese, Dutch and German colonialism and American chattel slavery on the one hand, and the economic impoverishment, racial dehumanization, cultural alienation and political oppression of African peoples on the other hand is the ideational progenitor that informs and substantiates the concept of Pan Africanism.

The experience shared by the majority of African descendant peoples that inform and substantiate the current world order is a direct consequence of several interrelated phenomena that have occurred beginning circa 1400 to 2017 (Esedebe, 1994; Murithi, 2005; Bunting, 2015).

- the emergence and expansion of capitalism

- the transatlantic slave trade, chattel slavery and human commodities stock market

- the creation of the idea of race and racial superiority

- European empire, militarism and colonialism in Africa, the Americas and Asia

- The global distribution of wealth and power which is skewed away from peoples of African descent and the African continent

- The endogenous resistance of Africans victimized within this phenomenon

What does a Pan African Political Culture entail? What does it mean? What objectives, principles, values inform it? What is its purpose? How can it be established? Why is it a solution to the inequities and conflicts of the current world order?

We begin with the premise that political change is a result of cultural changes; political culture consists of the values, beliefs and customs regarding how governments should relate to members of a society and how members of a society relate to each other. Political culture informs political ideology. Political ideology consists of a set of ideas regarding the role of government in a society (Nkrumah, 1964). The political ideology determines 
how government should be organized, what its purpose is, what it should do (policies), how power is derived, how resources are shared and distributed and to what ends as well as what the purpose and direction of its international relations. What is the political culture of the African Union, African states? What is the prevailing idea amongst Africans as to the role and purpose of government? Will the ideology and political culture be simply a poor facsimile of the imposed Eurocentric paradigm?

Pan Africanism is an ideology and an objective informed by the culture values, beliefs and customs of African peoples and their experiences that have developed over the past six centuries of the modern era. The experiences of African peoples and states have, over this epoch, been as both resisters to, and victims of, the systems, policies and practices of dehumanization and commodification of their bodies, lands and culture in capitalist relations within an imperialist framework. Since these dynamics are inherent to the global capitalist economic system, they persist to this day in the current capitalist world order. Ideologically Pan Africanism inherently posits that for Africa and African peoples to become 'whole' again the global imperialist economic and cultural system necessarily must be dismantled. The global edifice of White racial and cultural superiority must be dismantled. The military and prison industrial complex and the accompanying culture of militarism must be dismantled (Esedebe, 1994; Murithi, 2005; Bunting, 2015).

Over the past 30 years the political culture and ideological framework of global capitalism is the neo-liberal globalization paradigm. Within the Euro-American socio-economic, political and ideological framework political culture is informed with beliefs in individualism, social Darwinism, hierarchical racialism, and the myth narrative of 'the White Man's Burden', 'Manifest Destiny' and 'American Exceptionalism'. The ideology of EuroAmerica imperial confluence (Global NATO) is so called neo-liberal freemarket democracy and American exceptionalism (read white supremacy).

Capitalism is the idea, a belief system that spawns the capitalist economic system alongside a capitalist affirming political and social system. Similarly, socialism is an ideology that would spawn a socialist (people first) economic system. The idea of competition has permeated the political thought and process wearing a costume of democracy - however, beneath the costume, capitalism is inherently un-democratic, exploitative and antagonistically nonpeople centered (Arhin, 1993). Its adherents admit it is a competition and competition creates winners and losers and therefore antithetical to any Pan African purpose.

The values, purpose and ethos that have historically informed Pan Africanism and the revolutionary nationalism of African peoples' liberation movements embody democratic principles and objectives engendered within African social and political organization and experience. Pan African 
philosophical, people-centered, social and economic justice concepts, i.e. democratic concepts, that inform endogenous socio-political organization within African communities illustrate the value continuity of democratic principles that have been expressed by African peoples prior to and throughout the epoch of the Euro-American cultural and economic imperialist confluence (circa 1400-2000). In the absence of a Pan African political culture, these ideas have been relegated, however, and are not what guide our present socio-economic systems or our formulations of governance. Explicating the democracy discourse from the hegemony of the Euro-American centric narrative and capitalist's 'free-market' ideology and placing it within the context of endogenous Pan African socio-cultural values and aspirations enables African peoples' agency. Emancipating the narrative and relocating the discourse allows us to highlight the inaccuracies of the narrative that asserts democratic ideation among African peoples has only recently found space for expression as a phenomenon facilitated by exogenous factors put into motion by the end of the cold war and the defeat ( $\mathrm{sic}$ ) of socialism and the Soviet Union by the United States. (Cheru, 2002; Salih, 2001). Acceptance of, or giving credence to, this narrative discourse confirms the ideology of the preeminence of western neo-liberal free market democracy, the inevitability of capitalism and the correctness of ideological assertions of the Washington consensus.

Contextualizing the events of the African liberation wars, independence and civil liberties struggles and their substantiating motivations as African Voice provides a suitable space for examination of the relationship between power and voice, specifically the power to define and the subsequent social construction of reality through interactive human agency. Once the African narrative voice pronounces itself, it affirms the expression of the spirit and values of the centrality and democratic participatory power of the people and the social movements historically promoting these values.

There was collective democratic voice in the initial resistance to conquest and the subsequent anti-racist, anti-colonial, anti-imperialists struggles throughout the continent of Africa and the communities of African peoples dispersed throughout the Euro-American colonial empire. The liberation wars of southern Africa and the Pan African cooperative solidarity of support for these emancipatory democratic movements coupled with the civil and human rights struggles of Africans in the Americas and Europe characterize the essence of democracy located within endogenous Pan African political culture and informed by Pan African ideation of social and economic justice.

The collective actions of liberation and the Pan African cooperative solidarity emerged as people based political responses of oppressed nationalities, resisting the undemocratic institutions and social order of 
colonialism, imperialism, racism and economic injustice that characterized imperial globalization process of Occidental socio-cultural expansion and transnational hegemony (Mazrui, 1990). In an essay entitled, The Democratic Idea is Humanity, Alexander Crummel, a $19^{\text {th }}$ century Pan Africanists intellectual in 1888, explained, "The democratic idea is humanity" (Marable \& Mullings; 2000).

For Africa to realize Pan African political culture based on humanity centered, participatory self-governance, democracy, as a political practice and social objective necessarily cannot be a process that facilitates the elites' self-aggrandizement, a proliferation of patterns of conspicuous consumption and skewed wealth distribution substantiated by the religion of individualism. Rather it should manifest the cultural, historical and epistemological roots of the Pan African world experience and purpose. It must manifest the heritage of collectivity, democracy and socio-economic justice as imagined by Africans within their own cultural idiom (Othman, 2000).

Ideas of social and economic justice that embody reparations and equity are elemental to the Pan African political culture discourse. Social justice, reparatory justice, and equity must be differentiated from the concepts of natural justice and equality that underpin ideas of liberal western imperialist, capitalist and racialist political culture doctrines and theories (Shivji, 1991). A Pan African political culture necessarily addresses the issue of liberation from imperialist domination and social, economic and cultural diminishment that are the antithesis of the very essence of what Pan Africanism is and means. This in fact is what renders oxymoronic the democracy promotion narrative of Occidental institutions and governments like Global NATO, the IMF or the U.S. government. How can trans-national corporate capitalist imperial powers begin to promote democracy without first altering the power relationship between themselves and the populations of the nations over which they exercise dominion, denying them historical identity and agency (Othman, ed. 2000)?

Liberal multiparty electoral politics (competition politics), rule of law, human rights pronouncements and stock exchanges do not promote the aspirations of African people nor will they deliver wellbeing or transfer power to the weakest and most impoverished states and peoples. Quite the contrary, the dominant political economic construct does not offer a method of power redistribution, economic democracy or a platform for supporting popular democratic consensus. Popular livelihoods, popular power and popular participation constitute three integral elements of a Pan African political culture and democracy discourse (Shivji in Othman, 2000). These elements are antithetical to the neo-liberal free market-democracy construct currently promoted and imposed by the Euro-American imperialist confluence. 
Within the historical continuum of Pan Africanist's political culture 'popular' is a multiplex construct. Popular is anti-imperialist, rooted in the experience of the community of impoverished and working class people. Popular includes a participatory social agenda of equitable access to basic life affirming needs and respect of culture and customs. It relates to human agency and power. The Pan African political culture recognizes the conceptual difference between human beings and a people. Popular relates to 'A People' being the political factor when the phenomenon of power emerges in conjunction with that of people constituted in some form of self-determined social organization (Shivji in Othman, 2000).

An African centered critical pedagogy is required in order to create the cadre of the men and women capable of making the analysis as well as developing the policies, structures and systems necessary for the realization of Pan African objectives. Reparatory justice is an integral part of this calculus. The deconstruction of the imperial power status quo of Euro-America Global White supremacy will come about by the very process of African governments, peoples, institutions, clubs and organizations mobilizing and creating the Pan African Political culture and creating an All African Union Government.

Despite the general acceptance of these truisms, a state of confusion, contention and lack of political will keeps African organizations, governments and citizens from creating the critical mass of activism and policies necessary to bring about the conditions for the realizations of AU 2063 Agenda as well as all other grass roots, people generated Pan African aspirations. The absence of the functional Pan Africanist institutions and Pan African political culture leaves a powerless and directionless vacuum.

The argument of this work is that Pan African Political Culture must exist in order to realize any Pan African objective and aspiration. The African Union Agenda 2063 lays out a veritable shopping list of aspirations and goals for Africa and African people under the idea of 'The Africa we want' by year 2063. 'Aspiration 2' makes a series of declarative statements that embody ideas and values of Pan Africanism. It boldly states that Africa shall be a United Africa, peaceful, sovereign, independent, confident and selfreliant with world class, integrative infrastructure with seamless borders (an apparently oxymoronic proposition since borders by definition are 'seams'), and management of cross-border resources through dialogue (African Union Commission, 2015).

While acknowledging the need for dynamic and mutually beneficial links with the 'African Diaspora' it says nothing regarding the role of Africa in mitigating the life negating conditions, persistent structural impoverishment, exploitation, political and socio-economic marginalization, murder and mass incarceration of the African descendant peoples linked to racism, capitalism and white supremacy social framing (U.N. Human Rights Council; 2016). 
The AU Agenda 2063 does declare, however, that Africa will witness the rekindling of solidarity and unity of purpose that underpinned the struggle for emancipation from slavery, colonialism, apartheid and economic subjugation. However, it fails to state to what ends or what actions the rekindling of that revolutionary disposition are to be. One is compelled to wonder whether the African Union has considered what happens when the powers such as the US, the EU, Israel or Global NATO (Campbell, H. 2013) decide these AU agenda aspirations are contrary to their national interests.

I do not raise this mockingly; rather, I speak from concerned experience based upon what happened because of the perceived threat that establishing of a Pan African currency based on the Libyan Gold Dinar, posed to the economic, financial hegemony of the EU/USA imperial confluence (Global NATO). The African currency plan envisaged African countries having an alternative to the Bretton Woods institutions' imperial control of financial and monetary regimes in Africa. In that context the AU plan for a ceasefire, dialogue and governmental reform to stop the invasion of Libya and the murder of the Libyan head of state was rejected and blocked from being implemented by the US and its European allies (Campbell, 2013).

Considering NATO's arrogant and dismissive disregard of the African Heads of State and the AU exhibited in the Libyan fiasco, and the influential power of AFRICOM's US Africa Army within the AU and amongst individual African governments, the neo-liberal economic policies of the majority of AU member states and the artificial non-democratic democracy movement, a simple, logical and fundamental observation begs the question - how can the AU Agenda be fulfilled by 2063, when currently, across the global Pan African world, there are no schools, institutes or government programs that progressively and aggressively teach and inculcate the values, knowledge and ideological perspectives (pan African political culture) necessary to mitigate the structural and ideological impediments to the realization of AU Agenda 2063 aspiration?

The challenges are immensely complex. Declarations and pronouncements can help set goals. They must also generate studied debate and input from the masses of the global African family to come to fruition. This needs to happen immediately if not sooner in order to mobilize Pan Africanists and Pan African Institutions, including the African Union, to revitalize the Global Pan African Movement and traverse the gap between African governments' state centric approach and the endogenous grass roots, non-governmental and revolutionary programmatic expressions of peoplecentric Pan Africanism. Since we intend to generate a dynamic for the Pan African Movement and actualize the African Union Agenda 2063. There is a paramount need for a general consensus of meaning, ideological clarity 
and shared strategic purpose of Pan Africanism that will harmonize and or mitigate the dissonant cacophony of ideas, sentiments, conflicting agendas, exclusivists tendencies and ideological dogmatism that proliferate at all levels of the Pan African world.

There is a general and oft spoken lack of confidence in African governments to be progressively Pan Africanist. Related to this, is a tactical consideration regarding the role and legitimacy of the African state in the Pan African project whereby concerns are raised as to whether or not the African Union by the very nature of the neocolonial African state, is inherently antithetical to realizing the most basic Pan African objective of establishing an all Africa Union government? In relation to the global African family, class dimension of African leadership elite and international protocol in regards to national sovereignty has produced a malaise of self-censorship and sociopolitical conservatism amongst most African governments. This translates into policies and actions that ignore the grassroots Pan African support and sentiments. Focus is on state to state cooperation and engaging the members of the Global African family that are 'safe' in terms of being non-confrontational and acquiescent to the Euro-American imperialist confluence's institutions and policies towards Africa.

Continental political unity, an all Africa Union Government, global Pan African solidarity, participatory democracy and the establishment of a non-capitalist people centered economy are most frequently expressed as quintessential ideas and objectives that define the Pan African purpose. The strength to build upon is the wide spread consensus reflecting a common wisdom such that any strategy intended to empower African peoples to control our political destiny, overcome imperialism, impoverishment, internal conflict, social dissonance, racial based oppression and the structural violence of global white supremacy a Pan African global mobilization is essential. Despite a broad recognition and pronouncements of the critical need for Pan Africanist's activism, there is an absence of cohesive and persistent effort, clarity of purpose and sustainable institutional support. Therefore, in order to that actualize the AU Agenda 2063 and the expressed Pan African aspirations of the Pan African world community, a Pan Africanist political culture must be inculcated, nurtured and institutionalized throughout the continent of Africa and the global African family.

\section{Conclusion}

An essential but neglected element is the creation and nurturing of a Pan African political culture. The distribution of power and resources within the current world order is substantiated by a racialist ideology and a hegemonic imperialist political culture predicated upon the creation and maintenance of a subaltern Africa and subaltern African people. Modern educational, political, 
cultural and financial institutions are inherently and purposely diametric opposite to any program of reparatory justice, political empowerment, cultural self-determination and economic democracy for Africa and African peoples. A united Africa and Pan Africanism as both an objective and political ideology are key elements for African peoples to secure economic prosperity and justice, political emancipation and cultural self-determination (Nkrumah, 1963 ; 1964).

However, since the end of legal apartheid in South Africa, the decommissioning of the OAU liberation committee, the imposition of and acquiescence to structural adjustment of the neo-liberal economic paradigm, its accompanying political dispensation of 'free-market democracy' and the Global War on Terror, there has been a steady decline in Pan African solidarity, purpose and action amongst African governments and throughout the Pan African world. There was a shared African identity of purpose linked to resistance, aspirations of unity as a means to power and hope for a more prosperous and dignified future that underpinned nationalist and Pan African sentiments. These sentiments and ideologies were nurtured and channeled into a sense of African unity of purpose to overthrow colonialism, inspire nation building, state consolidation and social justice movements throughout the world of African peoples. Gradually, however, the emancipatory and revolutionary nationalism and internationalist Pan African solidarity that motivated and sustained the anti-colonial, anti-imperialist, anti-racialist movements lost its progressive trajectory, succumbing to neo-colonial imperialist hegemony. The growing impoverishment of the majority of African people and social antagonisms produced by neoliberal imperialism micro-nationalisms and nativists xenophobia are on the rise, furthering the distance from Pan African objectives and necessities. Within an African centered critical pedagogy coupled with a Pan African political culture and reparations lie the solutions and the healing.

Africans collectively experienced the expansion of western capitalism in the form of military, religious and economic structures. The epochal institutionalization of a subaltern identity and lived experience of Africans generated a sentiment and identity of unity and resistance respectively. This aspiration of unity as defense and resistance as purpose directly related to the oppression and exploitation inherent in the capitalist/imperialist confluence and the imposed identity and status qualifier of Black subaltern. However, Pan African aspiration of socio-economic prosperity, politico-cultural selfdetermination and unity have been thwarted and often misdirected. In order to overcome the forces working against or negating Pan African Purpose a critical pedagogy informed by an African centered curriculum is necessary.

Political culture refers to the set of shared values, beliefs amongst citizens and between citizens and government regarding their relationships 
in the function and purpose of government. Political ideology underpins political culture. Pan Africanism as collective endogenous ideation emerged as a direct consequence of African peoples' encounter with the hegemonic expansion of occidental culture and its modern manifestations of capitalism, anti-black racism, African enslavement, colonialism and imperialism.

This work recognizes Pan Africanism as the collective expression of the convergence of ideas, sentiments of endogenous cognitive interests of African peoples manifest in aspirations, policies and practices both at the state level of cooperation and as a grass roots movement in the Pan African world. There appears to be a need to re-member and resurrect the ideological and cultural foundations of the movements for African Unity, resource redistribution (class struggle) and anti-racism aspects of the wars for liberation and self-determination, civil liberties and rights throughout the global African family. By reclaiming the power to define reality within the Pan African world perspective we give value and clarity to the efforts and highlight the values and sentiments that informed the collective efforts of millions of Africans globally to rid the continent of Africa and African descendant peoples and indeed the world of white supremacy, neo-colonialism and imperialism.

Let us resolve to create an All African Union Government mobilization campaign and movement with a mass participation that includes trade unions, educators, artists, women's and youth organizations, farmers and African Union governments' representatives. Said movement will be well able and empowered to institute the steps for securing reparations, creating a critical African centered pedagogy and promoting a Pan African political culture. The ultimate objective is to unite Africa under a Union government and deconstruct the systems, mechanisms philosophies that negate the lives and wellbeing of members of the global African family and disrupt our legitimate aspirations for emancipatory power, African unity, peace, prosperity and cultural and epistemological self-determination. 


\section{References}

Abango, G. (Ed.) (2003). Issues and trends in Contemporary Afrikan Politics: New York: Peter Lang Publishers.

African Union (AU) (2015). Agenda 2063: The Africa We Want. African Union Commission.

Ani, M. (1994). Yurugu: An African Centered Critique of European Cultural Thought and Behavior. Trenton, NJ: African World Press.

Arhin, K. (1993). The Life and Work of Kwame Nkrumah. Trenton, NJ: Africa World Press.

Asante, M. (1990). Kemet, Afrocentricity and Knowledge. Trenton, NJ: African World Press

Ayittey, G. (1991). Indigenous African Institutions. Transnational Publishers. Bunting, I. (2015). "Developmentalism, Tanzania, and the Arusha

Declaration: Perspectives of an Observing Participant." In Radcliffe, K., Scott, J., Wener, A. (Eds.), Anywhere But Here: Black Intellectuals in the Atlantic World and Beyond (65-96). Jackson, MS: University Press of Mississippi.

Cabral, A. (1979). Unity and Struggle. New York \& London: Monthly Review Press.

Campbell, H. (2013). Global NATO and the Catastrophic Failure in Libya:

Lessons in the Forging of African Unity. New York: Monthly Review Press

Cheru, F. (2002). The African Renaissance: Roadmaps to the Challenge of Globalization. London: Zed Books Ltd.

Chinweizu, I. (1987). Decolonizing the African Mind. Lagos: Pero Press. Chinweizu, I. (1975). The West and the Rest of Us. London: Sundor. Chomsky, N. (1987). On Power and Ideology, The Managua Lectures. Boston: South End Press.

Booth, D. (Ed.). (1994). Rethinking Social Development: Theory, Research and Practice. Harlow: Longman.

Depelchin, J. (2004). Silences in African History: Between Syndromes of

Discovery and Abolition. Dar Es Salaam: Mkuki na Nyota Publishers. DeWitt, L. (2002). The Assassination of Patrice Lumumba. London: Verso. Dubois, W.E. B. (2007). The World and Africa, Color and Democracy (Gates, L. H., Ed.). New York: Oxford University Press. (Original work published 1965).

Dudley, William (Ed.). (2000). Afrika, Opposing View Points. San Diego: CA: Green Haven Press, Inc.

Encyclopedia of American Foreign Policy www.americanforeignrelations. com/O-W/Post-cold- War-Policy-Promoting-democracy.html 
Esedebe, P.O. (1994). Pan Africanism: The Idea and Movement, 1717-1991. ( $2^{\text {nd }}$ Ed). Washington D.C: Howard University Press.

Fafunwa, A. B. \& Aisiku, J. U. (Eds.). (1982). Education in Africa. London: George Allen \& Unwin Pub. Ltd.

Fanon, F. (1963). Wretched of the Earth. New York: Grove Press. Fanon, F. (1967). Black Skins White Masks. New York: Grove Press. Fanon, F. 1989. Studies in a Dying Colonialism. London: Earth Scan Publication.

Floyd, D. African America News Service; Third World Network http://www. twnside.org.sg accessed 2/22/2009

Freire, P. (1993). Pedagogy of the Oppressed. New York: Continuum Publishing Co.

Giroux, H. (2010, November 23). Lessons to be Learned from Paulo Freire as Education Is Being Taken Over by the Mega Rich. Truthout Op-Ed. Retrieved from https://truthout.org/articles/lessonsto-be-learned-from-paulo-freire-as-education-is-being-takenover-by-the-mega-rich/

Hill, R. (Ed). (1990). Walter Rodney Speaks: The Making of an African Intellectual. Trenton, N.J: Africa World Press.

Hilliard III, A. (1998). SBA : The Reawakening of the African Mind. Gainesville, FL: Makare Publishing Company.

Hochschild, A. (1998). King Leopold's Ghost. New York: Houghton Mifflin Company.

Houser, G. M. (1989). No one can stop the rain: Glimpses of Afrika's liberation struggle. New York, NY: Pilgrim Press.

Kpundeh, S. J. (1992). Democratization in Afrika: Afrikan views, Afrikan voices: summary of three workshops. Washington, D.C.: National Academy Press.

Lema, E., Mbilinyi, M., \& Rajani, R. (Eds.). (2004). Nyerere on Education:

Selected Essays and Speeches. Dar-es-Salaam, Tanzania: The

Mwalimu Nyerere Foundation.

Lewis, D. (Ed). (1995). W.E. DuBois: A Reader. Henry Holt and Company, New York.

Loewen, J. (1995). Lies My Teacher Told Me; Everything Your American History Text Book Got Wrong. New York, NY: New Press.

Long, N. and Long, A. (1992). Battle Fields of Knowledge: The Interlocking of Theory and Practice in Social Research and Development.

London: Routledge.

Marable, M \& Mullings, L. (Eds) (2000). Let Nobody Turn Us Around:

Voices of Resistance and Reform. Lanham, Boulder, New

York, Oxford: Rowan \& Littlefield Publishers Inc. 
Mazrui A. (1990). Cultural Forces in World Politics. London: James Curry Publishers.

Mudembe, V.Y. (1988). The Invention of Africa: Gnosis Philosophy and the Order of Knowledge. London: James Curry Publishers.

Murithi, T. (2005). The African Union: Pan Africanism, Peace Building and Development. Burlington, Virginia: Asgate publishing Company. Mwakikagile, G. (2006). Africa and America in the Sixties: A Decade that

Changed the Nation and a Destiny of a Continent. Pretoria and Dar

Es Salaam: New Africa Press.

Nkrumah, K. (1963). Africa must Unite: London Heinemann.

Nkrumah, K. (1964). Consciencism: Philosophy and Ideology for De-

Colonization: New York \& London: Modern Reader Paperbacks.

Nyerere, J.K. (1967). Education for Self-Reliance. Dar es Salaam:

Government Printer.

Nyerere, J.K. (1968). Uhuru na Ujamaa. London: Oxford University Press.

Othman, Haroub (Ed.). (2000). Reflections on Leadership in Afrika, Forty years after Independence. Institute of Development Studies,

Brussels \& Dar Es Salaam: VUB University Press.

Padmore, George (Ed.). (1963). History of the Pan-Afrikan Congress:

Colonial and Coloured Unity, a Programme of Action. London:

Hammersmith Bookshop, $2^{\text {nd }}$ edition.

Promoting democracy Encyclopedia of American Foreign Policy www.

americanforeignrelations.com/O-W/Post-cold-War-Policy-

Promoting-democracy.html

Roediger, D. (1994). Towards the Abolition of Whiteness. London: Verso.

Said, E. (1993). Culture and Imperialism. New York: Vintage Books.

Said, E. (1979). Orientalism. New York: Vintage Books.

Salih, Mohamed M.A. (2001). Afrikan Democracies \& Afrikan Politics.

London: Pluto Press.

Salih, Mohamed M.A. (Ed.) (2005). African Parliaments: Between

Governance and Government. New York: Palgrave Macmillan.

Shivji, I. (1991). The Democracy Debate in Africa: Tanzania. Review of African Political Economy, No. 50, Africa in a New World Order, 79-91.

Shivji, I. (2009). Where is Uhuru?: Reflections on the Struggle for

Democracy in Africa. Cape Town, Dakar, Nairobi, Oxford; Fahamu Books.

Shockley, Kmt G. and Cleveland D. (2011). Culture Power and Education: The Philosophies and pedagogy of African centered Educators. The International Journal of Critical Pedagogy. Vol.3, No 3. 
Smith, M et al. (Eds.). (2006). Beyond the African Tragedy; Discourses on Development and Global Economy. Hampshire; Agate publishing Ltd.

Takaki, R. (1994). A Different Mirror. New York: Back Bay Books.

United Nations (U.N.) Human Rights Council. (2006). Working Group of Experts on People of African Descent on its Mission to the United States. 2016, A/HRC/33/61/Add.2.

United States' Public Law 109-456 of the $109^{\text {th }}$ Congress, Dec. 2006 “

Democratic Republic of the Congo Relief, Security and Democracy Promotion Act of 2006.

van Dijk, T.A. (1993). Elite Discourse and Racism. Sage Publications. van Hensbroek, B. P. (1999). Political Discourses in African Thought: Westport Ct.: Praeger Publishers. 